OPEN ACCESS

Edited by:

Naser A. Anjum,

Aligarh Muslim University, India

Reviewed by:

Mahaveer P. Sharma,

ICAR Indian Institute of Soybean

Research, India

Lei Wang,

Xinjiang Institute of Ecology and

Geography, Chinese Academy of

Sciences (CAS), China

${ }^{*}$ Correspondence:

Chase M. O'Neil

oneilch3@msu.edu

Specialty section:

This article was submitted to

Plant-Soil Interactions,

a section of the journal

Frontiers in Agronomy

Received: 26 June 2021

Accepted: 13 August 2021

Published: 01 September 2021

Citation:

O'Neil CM, Nash J, Tiemann LK and Miesel JR (2021) Mycorrhizal

Symbioses Enhance Competitive

Weed Growth in Biochar and

Nutrient-Amended Soils.

Front. Agron. 3:731184.

doi: 10.3389/fagro.2021.731184

\section{Mycorrhizal Symbioses Enhance Competitive Weed Growth in Biochar and Nutrient-Amended Soils}

\author{
Chase M. O'Neil ${ }^{1 *}$, Jake Nash ${ }^{2}$, Lisa K. Tiemann ${ }^{1}$ and Jessica R. Miesel ${ }^{1,3}$ \\ ${ }^{1}$ Department of Plant, Soil and Microbial Sciences, Michigan State University, East Lansing, MI, United States, ${ }^{2}$ Department \\ of Biology, Duke University, Durham, NC, United States, ${ }^{3}$ Program in Ecology, Evolution, and Behavior, Michigan State \\ University, East Lansing, MI, United States
}

Velvetleaf (Abutilon theophrasti) is a highly competitive weed in agroecosystems that is well-studied for its efficient nitrogen $(\mathrm{N})$ acquisition, yet research on its phosphorus $(\mathrm{P})$ uptake is lacking. One pathway may be through symbioses with arbuscular mycorrhizal fungi (AMF) which increase nutrient acquisition. These AMF benefits can be further enhanced by soil amendment with biochar, although effects may vary with different biochar production characteristics. We implemented a fully factorial nutrient and biochar addition experiment in a greenhouse for six months to determine how AMF nutrient uptake impacts plant growth and how these effects vary between two biochar types. We measured total above- and belowground biomass, plant tissue concentration ( $N$ and P), AMF colonization and activity rates, and soil media $\mathrm{N}$ and $\mathrm{P}$ availability. Overall, we observed few statistically significant results, however AMF N uptake may have been more beneficial to velvetleaf than AMF P uptake as evidenced by increased biomass and tissue $\mathrm{N}$ concentrations in treatments where $\mathrm{N}$ was only accessible by AMF. Additionally, by maintaining root to shoot ratios biochar may have provided plants with $\mathrm{N}$ and $\mathrm{P}$ (through sorption of nutrients to surfaces or its inherent properties) when nutrients were more difficult to access. We also found variable plant responses across the two biochar types used. Understanding how nutrient and biochar additions can influence weed competition is important for anticipating potential undesirable consequences of novel soil amendments such as biochar.

Keywords: arbuscular mycorrhizal fungi, velvetleaf, Abutilon theophrasti, nitrogen, phosphorus, nutrient uptake

\section{INTRODUCTION}

Velvetleaf Abutilon theophrasti is a financially devastating weed in the upper Midwest and Eastern United States (Spencer, 1984). While velvetleaf primarily reduces crop yield by shading out other plants (Akey, 1989; Lindquist and Mortensen, 1999), aboveground biomass increases may be due to successful competition for nutrients belowground (Bonifas et al., 2005; Barker et al., 2006; Vitousek et al., 2010). For example, velvetleaf has a higher nitrogen (N) uptake efficiency than corn (Bonifas and Lindquist, 2006) likely because it can maintain its total root system length with less root biomass (Bonifas and Lindquist, 2009). Although belowground competition for $\mathrm{N}$ is welldocumented between velvetleaf and crops (Bonifas et al., 2005; Barker et al., 2006; Lindquist et al., 2007; Bonifas and Lindquist, 2009), competition for phosphorus (P) acquisition is less studied. One potentially advantageous way to compete for $\mathrm{P}$ may be through symbioses with arbuscular mycorrhizal fungi (AMF) (Smith and Read, 2008). 
Arbuscular mycorrhizal fungi (AMF) colonize plant root systems and increase nutrient uptake through hyphal networks that grow outside the root depletion zone (Sanders and Tinker, 1971; Smith and Read, 2008). Velvetleaf is a "strong" AMF host with higher colonization rates compared to other agronomic weed species (Vatovec et al., 2005); both biomass and nutrient shoot tissue concentrations increase when colonized by AMF in the field (Stanley et al., 1993). Therefore, AMF symbioses could enhance velvetleaf $\mathrm{P}$ uptake and help the weed outcompete weak ( $<10 \%$ colonized) or non-mycorrhizal (e.g., sugar beets, cabbage, or kale) crops (Ocampo et al., 1980; Li et al., 2016). Furthermore, symbioses may also allow mycorrhizae to access $\mathrm{P}$ from plant-inaccessible sources, such as organic or insoluble nutrients (Jayachandran et al., 1992; Tarafdar and Marschner, 1994; Feng et al., 2003). Research has traditionally focused on $\mathrm{P}$ uptake because its slow recycling and low solubility in soil reduces plant uptake (Sanders and Tinker, 1971; Mosse, 1973; Holford, 1997). However, recent work has showcased the importance of AMF $\mathrm{N}$ transport and its potential benefits for plant growth (Hodge and Fitter, 2010; Smith and Smith, 2011; Hodge and Storer, 2014). Therefore, additional research examining how AMF-colonized velvetleaf respond to both $\mathrm{N}$ and $\mathrm{P}$ sources is needed. Such information is vital to understanding velvetleaf competitive abilities, especially for agroecosystems that apply $\mathrm{N}$ and $\mathrm{P}$ amendments to soils.

AMF benefits may be further amplified by biochar, a soil amendment that is increasingly being applied in agroecosystems. Produced from pyrolyzed biomass (Lehmann and Joseph, 2009), biochar is proposed for augmenting soil health (Glaser et al., 2001) and sequestering carbon (Smith, 2016; Du et al., 2017), but has also been found to increase AMF colonization (Warnock et al., 2007; Lehmann et al., 2011) and crop yield (Jeffery et al., 2011). Unfortunately, because biochar generally promotes plant growth (Biederman and Harpole, 2013) it may also increase weed biomass (Major et al., 2005; Nash et al., 2021). Thus, strong AMF weed hosts such as velvetleaf may become more competitive when colonized in biochar-amended soils. However, these effects can also vary greatly among biochar production methods, biomass feedstock types, and different soil conditions (Keiluweit et al., 2010; Jeffery et al., 2011; Cantrell et al., 2012; Clark et al., 2019). Therefore, while some studies suggest biochar can enhance AMF effects (Warnock et al., 2007; Gujre et al., 2021), there is a lack of information quantifying how different biochar types impact weed growth and potential for increased weedcrop competition.

We conducted a six-month greenhouse study to assess how nutrient additions and biochar affect weed competitive abilities, using velvetleaf as a model weed species. We tested three hypotheses: (1) P uptake by AMF will increase weed growth and nutrient tissue concentrations more so than $\mathrm{N}$ uptake; (2) biochar will enhance AMF colonization and therefore nutrient acquisition and plant growth; and (3) biochar's effects on plant growth will vary across nutrient treatments (interactive effects). Understanding how nutrient and biochar additions may enhance weed-crop competition will ultimately inform biochar application practices and help ensure agricultural producers avoid undesirable consequences of these novel soil amendments, especially in areas with strong AMF weed species.

\section{METHODS}

\section{Biochar}

We used two pyrolysis biochars (hereafter: BGR, USB) to assess differences between biochar types. The BGR biochar was produced from forest harvesting residues (Pinus resinosa and $P$. banksiana) from the Upper Peninsula of Michigan, USA, and pyrolyzed in a rotary reactor system at $650^{\circ} \mathrm{C}$ for $30 \mathrm{~min}$. The USB biochar was produced from waste wood pallets (southern yellow pine species), pyrolyzed in a continuous carbonizer at $550^{\circ} \mathrm{C}$ for $18 \mathrm{~min}$. To eliminate mineral ash effects from fresh biochar, we soaked biochars with $0.1 \mathrm{M} \mathrm{HCl}$ for $72 \mathrm{~h}$ and thoroughly rinsed with water. After this weathering treatment, biochar $\mathrm{pH}$ was $7.26 \pm 0.15$ and $7.14 \mathrm{~g} \pm 0.01$ and dry densities were 0.19 and $0.30 \mathrm{~g} / \mathrm{cm}^{3}$ for BGR and USB, respectively.

\section{Experimental Design and Establishment Period}

We implemented a factorial mesocosm experiment in a greenhouse, using three biochar treatments (BGR, USB and a No Biochar control) and four nutrient addition treatments, with five replicates per treatment (60 total mesocosms). We created biochar treatments by mixing each biochar type with a commercially washed and screened sand (3\% silt) at $12 \%$ volume, which equates to a field application rate of $50 \mathrm{Mg} \mathrm{ha}^{-1}$. We chose this high rate to help determine upper thresholds where carbon sequestration is maximized, and plant health is maintained. Biochar and sand mixtures were combined in a cement mixer to ensure even mixing and then steam-sterilized overnight.

We created mesocosms using $12.7 \mathrm{~cm} \times 12.7 \mathrm{~cm} \times 30.5 \mathrm{~cm}$ square pots that we divided into three compartments: two side "plant" compartments and a center "nutrient" compartment. The compartments were separated with plastic sheeting, into which we established a $10 \mathrm{~cm} \times 10 \mathrm{~cm}$ window comprised of $50 \mu \mathrm{m}$ nylon mesh (Elko Filtering Company) secured with silicon caulk. The mesh window allowed fungal hyphae to pass through but excluded plant roots. We filled each mesocosm compartment with the appropriate biochar + sand treatment (all compartments within a given pot received the same biochar + sand treatment). We then placed AMF whole inoculum $(1.2 \mathrm{~g}$ per mesocosm, International Culture Collection of Vesicular Arbuscular Mycorrhizal Fungi, West Virginia University) in $7.5 \mathrm{~cm}$ deep holes in each plant compartment and filled the holes leaving a shallow indentation $(\sim 0.75 \mathrm{~cm}$ deep) for seeds. The whole inoculum included roots, spores, hyphae, and growth medium of AMF species Gigaspora rosea (120-150 spores per g), Rhizophagus clarus (220-250 spores per g), and R. irregularis (250-300 spores per g). Velvetleaf seeds (collected from MSU's Agriculture Research Farm, $42^{\circ} 42^{\prime} 38.2^{\prime \prime} \mathrm{N}, 84^{\circ} 28^{\prime} 16.6^{\prime \prime} \mathrm{W}$ ) were planted on May 3rd in each shallow hole on top of the inoculum to ensure contact with seedling roots and covered with media. We planted additional seeds in compartments that had not germinated on May 10th and May 16th, with all germination occurring by May 20th. Then, we thinned seedlings 
to two plants per mesocosm, one in each plant compartment. Germination did not occur in some plant compartments $(\sim 11 \%)$, so we transplanted the extra seedlings from other mesocosms within the same biochar treatment. Mesocosm treatments were placed randomly on the greenhouse table and maintained under supplemental lighting ( $16 \mathrm{~h}: 8 \mathrm{~h} \mathrm{~L}: \mathrm{D})$ at $\sim 20^{\circ} \mathrm{C}$, with daily watering through an automated sprinkler system. To ensure all plants had access to basic nutrient supply needed to establish initial growth, we fertilized mesocosms with $200 \mathrm{ml}$ of $0.5 \mathrm{X}$ Hoagland solution (Hoagland and Arnon, 1950) twice a week from May 3, 2019 to July 23, 2019 (12 weeks). Because carbonates in the sand led to a media $\mathrm{pH} \sim 9$, we acidified the Hoagland solution to $\mathrm{pH} 5.5$ with $\mathrm{HCl}$ to create conditions more favorable to plant growth.

\section{Nutrient Treatment Period}

On July 23, 2019 we stopped regular Hoagland applications and initiated four nutrient addition treatments to test how $\mathrm{N}$ and $\mathrm{P}$ uptake by mycorrhizae influences velvetleaf competitiveness. Each nutrient treatment combined (a) a weekly application $(100 \mathrm{~mL})$ of a modified Hoagland's solution with soluble $\mathrm{N}$ and/or $\mathrm{P}$, accessible to both AMF hyphae and plants, and (b) an insoluble, organic $\mathrm{N}$ and/or $\mathrm{P}$ substrate tube added to each mesocosm's central compartment, accessible to AMF hyphae but not plant roots. This was designed to ensure that plants could only utilize the organic substrates if AMF proliferated through the mesh windows into the central compartment, where they could then solubilize the organic nutrient sources (e.g., excreting extracellular enzymes or stimulating other microbes to do so) and then transport the resulting inorganic ions to the plant (Frey, 2019). By limiting nutrient acquisition to AMF only, we can better quantify symbiosis impact on plants. Treatments were: (1) Soluble NP (Sol NP), (2) Insoluble N and Soluble P (Insol N + Sol P), (3) Insoluble P and Soluble N (Insol P + Sol N), and (4) Insoluble NP (Insol NP) (Figure 1).

To create the organic substrate tubes, we constructed $50 \mu \mathrm{m}$ fine nylon mesh windows (Elko Filtering Company) on $50 \mathrm{~mL}$ centrifuge tubes (polypropylene, Fisher Scientific). We then used a blender to homogenize organic $\mathrm{N}$ (gelatin, $3 \mathrm{~g}$ per tube, 0.06 $\mathrm{g} / \mathrm{ml}$ ) and/or $\mathrm{P}$ (calcium phytate, $0.3 \mathrm{~g}$ per tube, $0.006 \mathrm{~g} / \mathrm{ml}$ ) with biochar + sand media and filled the tubes with these mixtures. Organic substrate concentrations were calculated to equal the total amount of soluble $\mathrm{N}$ or $\mathrm{P}$ applied via modified Hoagland solutions over the course of the experiment. We deployed the substrate tubes (top of tube flush with soil surface) in the center mesocosm compartment. We modified Hoagland solutions by excluding soluble $\mathrm{N}$ and/or $\mathrm{P}$, depending on treatment.

\section{Sample Collection and Processing}

After 11 weeks of nutrient treatments, we harvested the plants and separated shoots from roots at the root collar. We collected media samples from each mesocosm by shaking the residual biochar + sand media from the roots of both mesocosm plants into $50 \mathrm{~mL}$ tubes. We then clipped five $1.0 \mathrm{~cm}$ samples of fine roots from each of the two plants in the mesocosm and stored at $4^{\circ} \mathrm{C}$. Plant samples were rinsed with water, dried at $60^{\circ} \mathrm{C}$ for $48 \mathrm{~h}$ and weighed before grinding (Wiley mill, $1.0 \mathrm{~mm}$ mesh screen).

\section{Laboratory Analysis and Calculations}

Ground plant samples were analyzed for total $\mathrm{P}$ concentration by ashing samples at $500^{\circ} \mathrm{C}$ for $5 \mathrm{~h}$ and then digesting with $3 \mathrm{~N}$ nitric acid. Samples were then diluted $(1: 9$ with $0.3 \mathrm{~N}$ sodium hydroxide) before analysis via the ascorbic acid method (John, 1970). We pulverized ground plant tissues using a roller-mill and determined total $\mathrm{C}$ and $\mathrm{N}$ concentrations (Costech ECS $4010 \mathrm{CN}$ analyzer, Valencia, CA USA). We calculated above- and belowground biomass values by weighing both mesocosm plants and dividing by two to get average biomass per mesocosm. We then added above- and belowground biomass values to get total net primary production (NPP).

We measured AMF colonization of plant roots to interpret AMF benefits on nutrient uptake and plant response (Treseder, 2013). Although colonization rates can vary across AMF species (Treseder, 2013), our plants were inoculated with the same three species. We rehydrated roots $24 \mathrm{~h}$ before staining and colonization counting procedures (Phillips and Hayman, 1970; McGonigle et al., 1990). Root tissues were cleared with 10\% $\mathrm{KOH}$, stained with $0.05 \%$ Trypan Blue, de-stained with 5\% acetic acid, and mounted on microscope slides. Each slide contained five $1.0 \mathrm{~cm}$ roots from each mesocosm. We examined slides under a compound microscope at 400x magnification, with 20 fields-of-view per root. For each field-of-view, we scored presence or absence of mycorrhizal hyphae, vesicles, and/or arbuscules as colonized or not colonized, respectively. We calculated colonization percentage as the total number of colonized views divided by total field-of-views multiplied by 100 . We did not differentiate between AMF species and assumed that steam sterilization removed most all other mycorrhizae besides those in our inoculum (Brito et al., 2009).

We also measured extraradical hyphal length density (ERH) in organic substrate tubes as a proxy for AMF activity (Jakobsen et al., 1992; Staddon et al., 1999). We rinsed each organic substrate tube contents with $\mathrm{H}_{2} \mathrm{O}$ and decanted through a sieve stack (top: $500 \mu \mathrm{m}$, bottom: $212 \mu \mathrm{m}$ ). We then stained residues on the $212 \mu \mathrm{m}$ sieve with $0.05 \%$ Trypan blue stain (lacto-glycerol) and incubated for $30 \mathrm{~min}$. The stained residue was rinsed and mixed with $200 \mathrm{ml}$ of $\mathrm{H}_{2} \mathrm{O}$, and $20 \mathrm{~mL}$ was collected and vacuum-filtered $(0.45 \mu \mathrm{m}$ nylon filter). Two filters for each mesocosm were mounted on microscope slides and scored with 25 random fields-of-view at 10x objective magnification, 100x total magnification. For each field-of-view, we counted the number of times an AMF hypha crossed any gridline present in the reticle $(1 \mathrm{~cm}$ per side, $10 \times 10)$. We then used the average hyphal intersection counts per filter to calculate average hyphal densities (calculations in Supplementary Material).

We extracted inorganic $\mathrm{N}$ in media from each mesocosm using $25 \mathrm{~mL}$ of $0.5 \mathrm{M} \mathrm{K}_{2} \mathrm{SO}_{4}$ and $5 \mathrm{~g}$ media, and measured nitrate $\left(\mathrm{NO}_{3}^{-}\right)$via an enzyme reduction method (Patton and Kryskalla, 2011) and a microplate protocol for ammonium $\left(\mathrm{NH}_{4}^{+}\right)$(Sinsabaugh et al., 2000) (Biotek synergy H1, Winooski, VT, USA). We extracted phosphate $\left(\mathrm{PO}_{4}^{-}\right)$using $40 \mathrm{~mL}$ of $0.5 \mathrm{M} \mathrm{NaHCO}_{3}$ and $8 \mathrm{~g}$ of media, and analyzed concentrations using the molybdenum blue-ascorbic acid protocol (John, 1970) adapted for a microplate assay (Song et al., 2019). We ovendried media subsamples at $105^{\circ} \mathrm{C}$ for $48 \mathrm{~h}$ to calculate gravimetric 


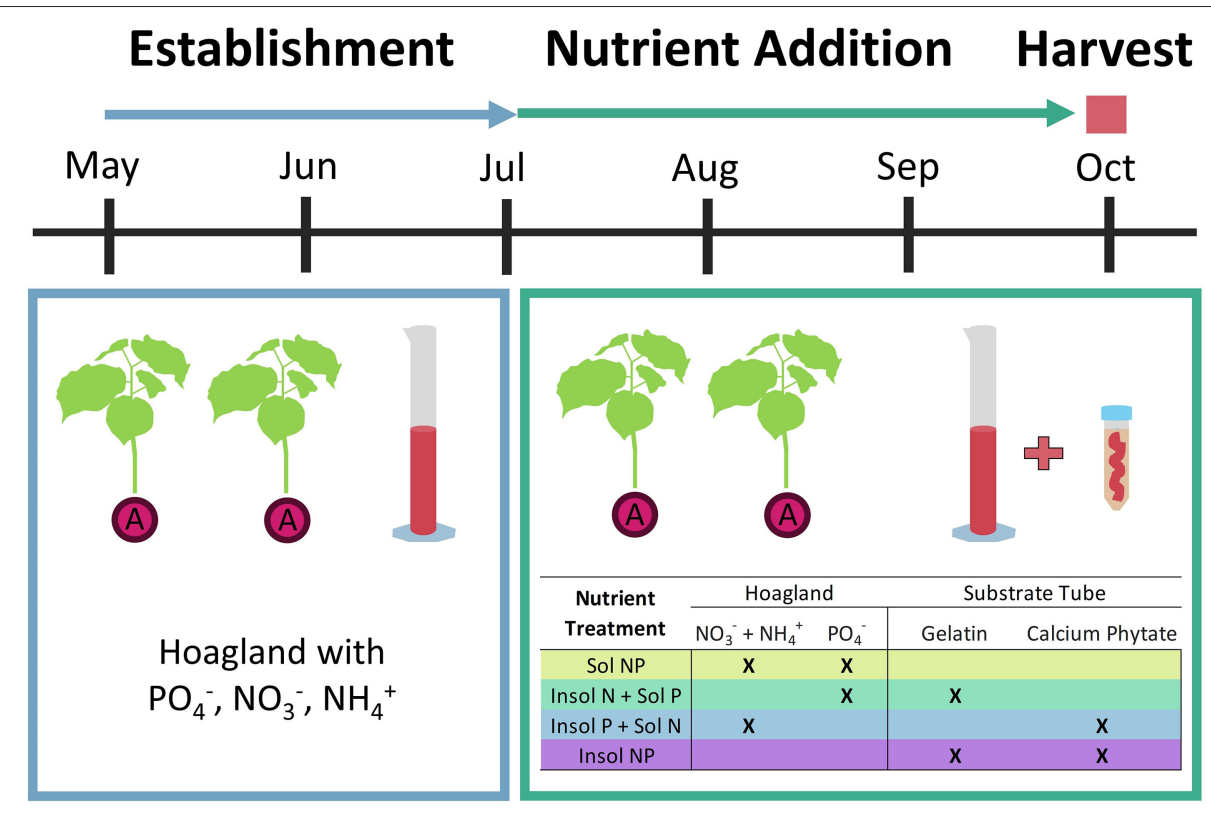

FIGURE 1 | The above diagram depicts the two phases of this experiment before harvest with each mesocosm represented by two AMF-colonized velvetleaf plants. During the establishment period, we applied Hoagland's solution (which contained both soluble N and P sources) to encourage plant establishment: adjusting to mesocosm and greenhouse conditions and forming relationships with mycorrhizal populations. In the nutrient addition period, we applied different combinations of modified Hoagland solutions (see table) and substrate tubes with insoluble $\mathrm{N}$ and/or $\mathrm{P}$ sources to better quantify mycorrhizal nutrient uptake benefits.

soil moisture and reported nutrient concentrations as a dry mass basis $\left(\mu \mathrm{g} \mathrm{g}^{-1}\right)$. We measured media $\mathrm{pH}$ as $1: 2 \mathrm{w}: \mathrm{v}$ in $\mathrm{H}_{2} \mathrm{O}$.

\section{Statistical Approach}

For all response variables, we performed fully interactive general linear models (multiple two-way analysis of variance) with biochar type and nutrient treatment as explanatory variables. Because of the unbalanced design (due to plant mortality, etc.), we used type III sum of squares. Statistical significance was determined when $p<0.05$. We performed pairwise comparisons using Tukey's tests, adjusted for multiple comparisons. For AMF colonization comparisons, we used a beta-distributed (response bounded by 0 and 1) mixed-effects linear model with a random effect of mesocosm ID to account for variation between the root replicates collected per mesocosm. For ERH comparisons, we used a normally-distributed mixed-effects linear model with a random effect of mesocosm ID to account for the variation between the two filters processed per mesocosm. We checked model assumptions visually by plotting residuals and predicted values and log-transformed any response variables that did not conform to normality assumptions. All analyses were performed using R statistical software version 3.5.3.

\section{RESULTS}

\section{Plants}

Belowground biomass was significantly affected by nutrient treatment $\left(\right.$ ANOVA, $\left.p=1.07 \times 10^{-4}\right)$. For treatments without biochar, belowground biomass in Insol NP treatments was
$63 \%$ higher than Sol NP treatments $\left(p=4.48 \times 10^{-3}\right), 29 \%$ higher than Insol $\mathrm{N}+$ Sol $\mathrm{P}$ treatments $(p \geq 0.05)$, and $69 \%$ higher than Insol $\mathrm{P}+$ Sol $\mathrm{N}$ treatments $\left(p=2.35 \times 10^{-3}\right)$ (Figure 2B). However, this relationship was not significant across biochar treatments (all $p \geq 0.05$ ). Additionally, there were no significant effects of nutrient treatment, biochar, or the nutrient $\times$ biochar interaction on aboveground biomass or total NPP (Figures 2A,C).

Nutrient treatment also significantly affected root:shoot biomass ratio (ANOVA, $p=7.85 \times 10^{-7}$ ) with similar trends to belowground biomass. For example, without biochar, root:shoot ratios were the highest in Insol NP treatments (Figure 2D). Root:shoot ratios in Insol NP treatments were $60 \%$ larger than ratios in Sol NP $\left(p=1.43 \times 10^{-4}\right), 38 \%$ larger than ratios in Insol $\mathrm{N}+$ Sol P $(p=0.04)$, and $61 \%$ larger than ratios in Insol $\mathrm{P}+$ Sol N $\left(p=1.24 \times 10^{-4}\right)$. Additionally, compared to No Biochar treatments, BGR and USB decreased the root:shoot ratio in Insol NP treatments by 42 and $27 \%$ respectively $\left(p=1.66 \times 10^{-3}\right.$, $0.05)$, but had no significant effects in other nutrient treatments (all $p \geq 0.05$ ).

Nutrient treatment significantly affected aboveground plant tissue N (ANOVA, $p=0.04$ ); however, post-hoc testing did not reveal statistically significant differences between treatments (all $p \geq 0.05$ ). Nutrient treatments had significant effects on belowground plant tissue $\mathrm{N}$ (ANOVA, $p=1.22 \times 10^{-3}$ ) that were similar to aboveground $\mathrm{N}$ tissue, but did not vary across biochar treatments (interaction, $p \geq 0.05$ ). Therefore, regardless of biochar treatment, tissue $\mathrm{N}$ concentrations were the highest in Insol $\mathrm{N}+$ Sol $\mathrm{P}$ treatments compared to all other nutrient 


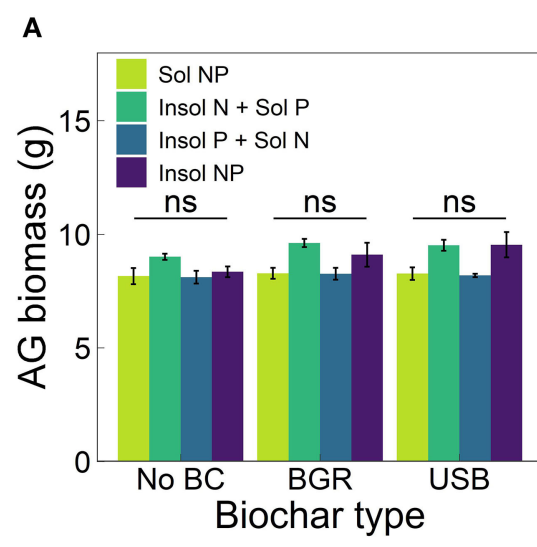

C

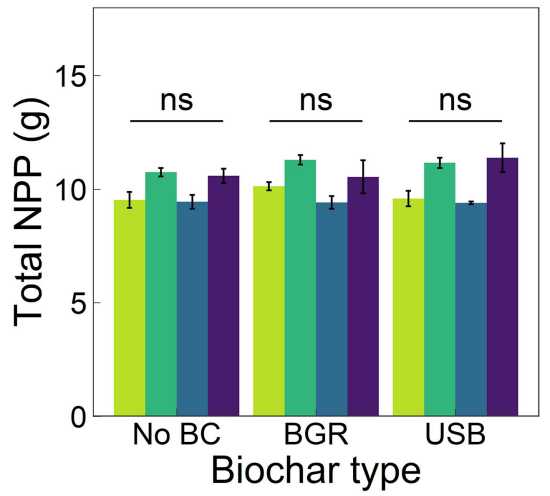

B

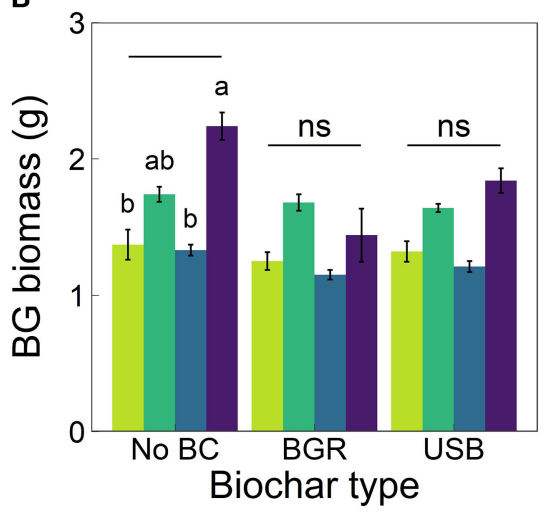

D

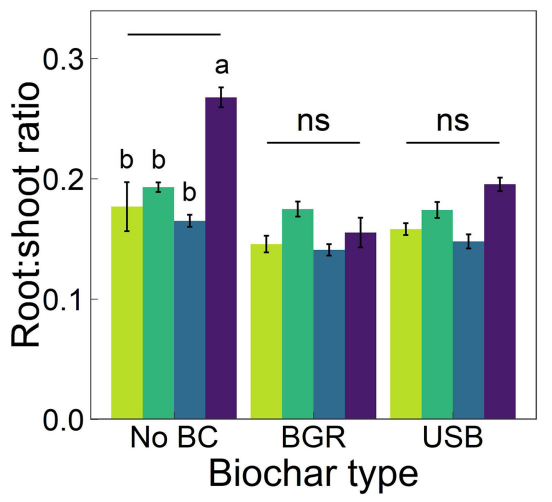

FIGURE 2 | Means ( \pm SE) of (A) aboveground (AG) and (B) belowground (BG) biomass, (C) total NPP (AG + BG biomass) and (D) root:shoot ratios for biochar (x-axis) and nutrient treatments (varied colors). Lowercase letters indicate significant differences (Tukey post-hoc tests, $p<0.05)$ among nutrient treatments within biochar type and "ns" indicates no significant differences. Significant differences among biochar types within nutrient treatments are displayed in

Supplementary Table 2. The x-axis label "No BC" stands for No Biochar treatments.

treatments in both above- and belowground tissue (Figures 3A, 3C); although, this relationship was only significant for BGR treatments in belowground tissue. In BGR, belowground $\mathrm{N}$ tissue in Insol $\mathrm{N}+$ Sol P treatments was 37\% higher than Sol NP $(p=$ $0.07)$ and $52 \%$ higher than both Insol $\mathrm{P}+\operatorname{Sol} \mathrm{N}\left(p=1.99 \times 10^{-3}\right)$ and Insol NP treatments $(p=0.05)$.

Biochar, nutrient, and biochar $\times$ nutrient interaction (ANOVA, $p=4.21 \times 10^{-8}, 6.7 \times 10^{-4}, 9.26 \times 10^{-7}$ ) all significantly affected belowground tissue $\mathrm{P}$ concentrations. Overall, BGR biochar decreased belowground tissue P compared to No Biochar treatments (Figure 3D). For example, BGR significantly decreased belowground plant tissue P by $38 \%$ for both Sol NP treatments $\left(p=9.71 \times 10^{-6}\right)$ and Insol NP $(p=$ $\left.6.6 \times 10^{-4}\right)$. Additionally, plant tissue $\mathrm{P}$ was $31 \%$ lower in BGR compared to USB Sol NP treatments $\left(p=5.85 \times 10^{-3}\right)$. For USB, belowground plant tissue $\mathrm{P}$ was 33\% lower in Insol $\mathrm{P}+$ Sol $\mathrm{N}$ treatments when compared to No Biochar $\left(p=1.51 \times 10^{-3}\right)$, although USB Sol NP treatments did not significantly differ from No Biochar Sol NP treatments (11\% difference, $p \geq 0.05$ ). Nutrient treatments had different effects on belowground tissue $\mathrm{P}$ within biochar types (Figure 3D). Within BGR, belowground plant tissue $\mathrm{P}$ was $53 \%$ higher in Insol $\mathrm{N}+$ Sol $\mathrm{P}$ compared to
Sol NP treatments $\left(p=3.43 \times 10^{-4}\right)$, however this relationship was reversed in No Biochar treatments $(p \geq 0.05)$. In USB biochar, plant tissue $\mathrm{P}$ was generally lower in Insol $\mathrm{P}+\mathrm{Sol} \mathrm{N}$ treatments with $32 \%$ less than Sol NP $\left(p=2.41 \times 10^{-3}\right)$ and $37 \%$ less than Insol NP $\left(p=6.86 \times 10^{-5}\right)$. Aboveground tissue P concentrations were significantly affected by biochar $\times$ nutrient interaction (ANOVA, $p=0.03$ ), however post-hoc tests did not reveal differences between treatments (all $p \geq 0.05$, Figure $3 \mathbf{B}$ ).

\section{Mycorrhizae}

Nutrient treatment significantly affected AMF root colonization (ANOVA, $p=7.31 \times 10^{-5}$ ) with rates generally highest in Insol $\mathrm{NP}$ or Insol $\mathrm{N}+$ Sol $\mathrm{P}$ treatments and lowest in Insol $\mathrm{P}+$ Sol $\mathrm{N}$ treatments (Figure 4A). In No Biochar treatments, root colonization was on average $161 \%$ higher in Insol NP treatments than Insol P + Sol N $\left(p=1.51 \times 10^{-3}\right)$. There were no significant effects of any treatment on AMF ERH (Figure 4B).

\section{Media Nutrient Availability}

Inorganic $\mathrm{N}$ and $\mathrm{P}$ media concentrations were low $\left(\mathrm{NO}_{3}^{-}\right.$and $\mathrm{NH}_{4}^{+}<4 \mu \mathrm{g} \mathrm{g}^{-1} ; \mathrm{PO}_{4}^{-}<1 \mu \mathrm{g} \mathrm{g}^{-1}$ ) but were generally higher in treatments with soluble $\mathrm{N}$ and soluble $\mathrm{P}$, for $\mathrm{NO}_{3}^{-}$and $\mathrm{PO}_{4}^{-}$ 

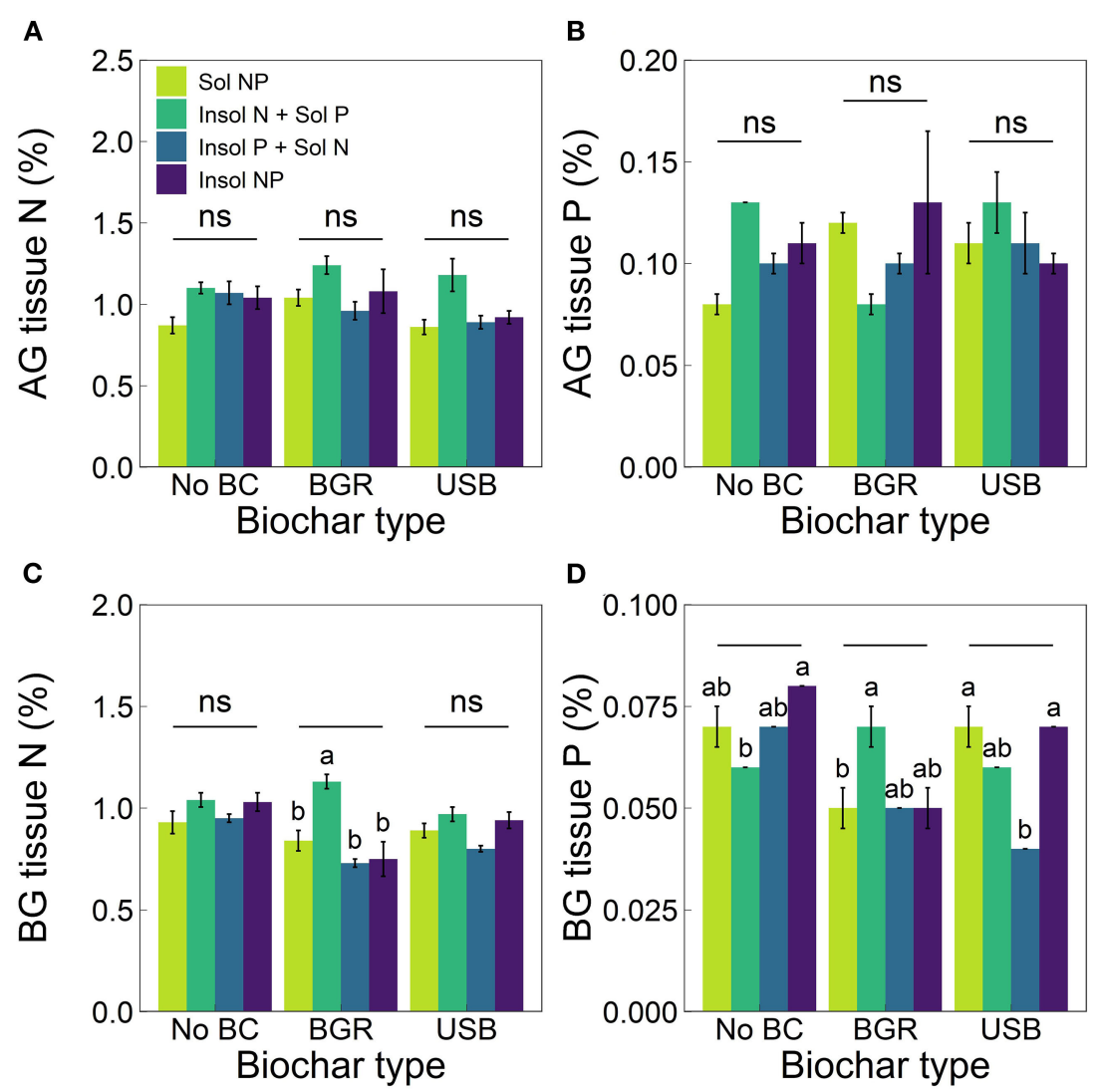

FIGURE 3 | Means ( \pm SE) of (A) aboveground (AG) total plant tissue N, (B) AG total plant tissue P, (C) belowground (BG) total plant tissue N and (D) BG total plant tissue $\mathrm{P}$ for biochar ( $\mathrm{X}$-axis) and nutrient treatments (varied colors). Lowercase letters indicate significant differences (Tukey post-hoc tests, $p<0.05$ ) among nutrient treatments within biochar type and "ns" indicates no significant differences. Significant differences among biochar types within nutrient treatments are displayed in Supplementary Table 2. The x-axis label "No BC" stands for No Biochar treatments.
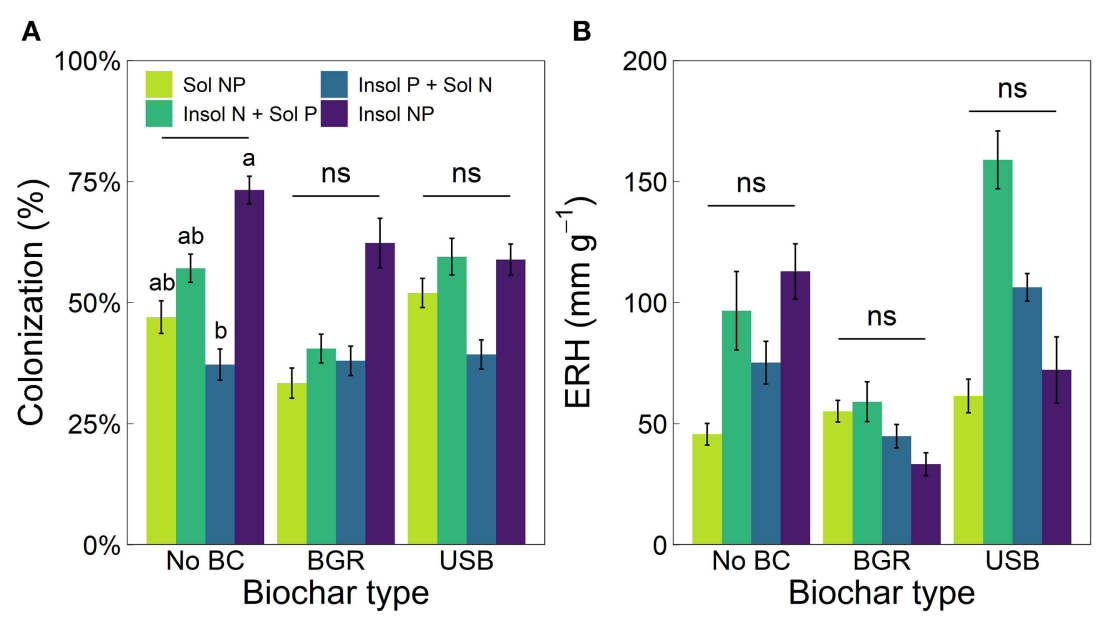

FIGURE 4 | Means ( \pm SE) of (A) AMF colonization and (B) extraradical hyphal length density (ERH) for biochar (x-axis) and nutrient treatments (varied colors). Lowercase letters indicate significant differences (Tukey post-hoc tests, $p<0.05$ ) among nutrient treatments within biochar type and "ns" indicates no significant differences. Significant differences among biochar types within nutrient treatments are displayed in Supplementary Table 2. The X-axis label "No BC" stands for No Biochar treatments. 
respectively (Supplementary Figures 1, 2). Despite this, none of our treatments significantly affected media $\mathrm{NO}_{3}^{-}, \mathrm{NH}_{4}^{+}$, total inorganic $\mathrm{N}\left(\mathrm{NO}_{3}^{-}+\mathrm{NH}_{4}^{+}\right)$nor $\mathrm{PO}_{4}^{-}$(Supplementary Table 1).

\section{DISCUSSION}

After a six-month greenhouse experiment, AMF-colonized velvetleaf grew and accumulated nutrients the most when AMF accessed insoluble $\mathrm{N}$, contrary to our original hypothesis on $\mathrm{P}$ uptake. Biochar altered and potentially improved weed root biomass growth, however, many biochar effects were neutral or non-significant, including impact on AMF colonization or activity rates. We also found some evidence for interactive effects between biochar and nutrient treatments (e.g., plant tissue $\mathrm{P}$ ), and our two similarly produced biochars caused variable plant responses.

Our results suggest that nutrient type and form may influence velvetleaf performance. Specifically, velvetleaf may have benefited more from AMF access to insoluble $\mathrm{N}$ vs. $\mathrm{P}$ sources. Plants in treatments with insoluble $\mathrm{N}$ substrate consistently (although not significantly) had higher NPP and above- and belowground $\mathrm{N}$ tissue concentrations compared to treatments with insoluble $\mathrm{P}$ and soluble $\mathrm{N}$ or soluble $\mathrm{N}$ and $\mathrm{P}$. This also suggests that plants grew more and accumulated more $\mathrm{N}$ from AMF uptake of insoluble $\mathrm{N}$ rather than plant and AMF uptake of soluble $\mathrm{N}$. Instead, soluble $\mathrm{N}$ may have leached from our sandy media before plants/AMF could acquire it and thus AMF N uptake from insoluble $\mathrm{N}$ was a more efficient pathway (Sexton et al., 1998). Other studies have also found AMF to utilize organic $\mathrm{N}$ sources (Hodge et al., 2001; Atul-Nayyar et al., 2009; Whiteside et al., 2012), with one reporting that organic patch $\mathrm{N}$ was responsible for $31 \%$ of fungal $\mathrm{N}$ and $3 \%$ of plant $\mathrm{N}$ (Hodge and Fitter, 2010) while another found one third of the patch's $\mathrm{N}$ to be transported to the plant by AMF (Leigh et al., 2009). Furthermore, AMF $\mathrm{N}$ uptake may be more valuable than $\mathrm{P}$ because some weeds respond more to high $\mathrm{N}$ availability (Blackshaw and Brandt, 2008), including velvetleaf which typically outcompetes corn in high $\mathrm{N}$ soils (Barker et al., 2006). AMF symbioses could therefore amplify velvetleaf competitiveness by increasing $\mathrm{N}$ acquisition from harder to access (or insoluble) nutrient sources. This also suggests that agricultural practices which apply these nutrients (e.g., slow-release organic $\mathrm{N}$ fertilizers, manure or crop residues) to promote soil fertility (Diacono and Montemurro, 2010) could actually promote AMF-colonized velvetleaf populations.

Low $\mathrm{N}$ availability may have increased insoluble $\mathrm{N}$ benefits, but also may have caused the neutral and non-significant biochar effects (Supplementary Table 2). Decreases in soil N availability, often caused by biochar (Gao et al., 2019), could potentially trigger neutral or negative responses for plants sensitive to $\mathrm{N}$ limitation (Gale et al., 2017; Liao and Thomas, 2019). Though our biochars did not significantly affect nutrient media availability (Supplementary Figure 1), our media appeared nutrient-limited (e.g., $\mathrm{pH} \sim 9$, low $\mathrm{NO}_{3}^{-}+\mathrm{NH}_{4}^{+}$), especially for N (Supplementary Figure 3, low N:P ratios). Thus, under $\mathrm{N}$-limited conditions, velvetleaf may have responded minimally to biochar. Neutral biochar effects could also be because our experiment was too short to observe biochar's more long-term beneficial effects (Liu et al., 2013; Lone et al., 2015). A longerterm experiment could reveal clearer differences between biochar types, as our variable plant and mycorrhizae responses make it difficult for managers to make informed decisions on what biochar to apply.

Both biochars did appear to alter weed biomass allocation strategies. In the No Biochar control, root:shoot ratios increased in Insol NP treatments when compared to Sol NP treatments, suggesting that velvetleaf increased root biomass when nutrients were harder to access. However, this relationship did not exist in biochar treatments. Biochar did not suppress plant growth, as aboveground biomass and NPP were unaffected, but may instead have acted as a nutrient source, either through its inherent properties (Yamato et al., 2006) or by retaining available nutrients through sorption (Schofield et al., 2019). Wood-based biochars typically release less $\mathrm{N}$ and $\mathrm{P}$ compared to other biochar feedstocks (e.g., poultry manure) (Piash et al., 2021), however they have been found to absorb available $\mathrm{N}$ (Fidel et al., 2018) and P (Zhang et al., 2016; Gao and DeLuca, 2018). Additionally, biochar pore sizes may prevent plant root access, however AMF hyphae are smaller than plant roots and can harvest $\mathrm{P}$ from biochar surfaces (Hammer et al., 2014). Thus, our biochars seemed to enhance weed growth belowground and could increase competition with crops in agroecosystems.

In conclusion, although our results did not support our original hypotheses, they suggest that insoluble $\mathrm{N}$ decomposition may play a more vital role than $\mathrm{P}$ decomposition in AMFvelvetleaf symbioses. Biochar may impact nutrient dynamics and consequent biomass allocation strategies for AMF-colonized plants. Biochar type also caused variable results, despite similar starting feedstocks. Thus, we found biochar and nutrient additions can enhance velvetleaf's competitive abilities in agroecosystems, although additional competition experiments in greenhouses and the field should be conducted. Further research should examine mechanisms of $\mathrm{N}$ and $\mathrm{P}$ access by AMF (Wang et al., 2017), especially insoluble sources, as well as how these processes interact with biochar. Such results can help guide agricultural management decisions that must consider velvetleaf (or other strong AMF weed hosts) when amending soils with nutrients and/or novel amendments such as biochar.

\section{DATA AVAILABILITY STATEMENT}

The raw data supporting the conclusions of this article will be made available by the authors, without undue reservation.

\section{AUTHOR CONTRIBUTIONS}

JN, LT, and JM conceived and designed the study. JN and $\mathrm{CO}$ performed the experiment and collected the data. CO and JM analyzed and interpreted the data. CO wrote the manuscript. All authors contributed to writing and approved the final submission. 


\section{FUNDING}

This study was supported by the Michigan Department of Agricultural and Rural Development, MSU Project GREEEN, and by McIntire-Stennis Project \#MICL06017. CO was supported by a Michigan State University Plant Sciences Fellowship.

\section{ACKNOWLEDGMENTS}

We thank Camryn Brent and Midhun Gelder for help with plant care, sample collection, and laboratory protocols and

\section{REFERENCES}

Akey, W. C. (1989). The role of competition for light in interference between velvetleaf (Abutilon theophrasti) and soybean (Glycine max) (Dissertation). Iowa State University, Ames, IA, United States.

Atul-Nayyar, A., Hamel, C., Hanson, K., and Germida, J. (2009). The arbuscular mycorrhizal symbiosis links $\mathrm{N}$ mineralization to plant demand. Mycorrhiza 19, 239-246. doi: 10.1007/s00572-008-0215-0

Barker, D. C., Knezevic, S. Z., Martin, A. R., Walters, D. T., Lindquist, J. L., Barker, D. C., et al. (2006). Effect of nitrogen addition on the comparative productivity of corn and velvetleaf (Abutilon theophrasti). Weed Sci. 54, 354-363. doi: 10.1614/WS-05-127R.1

Biederman, L. A., and Harpole, W. S. (2013). Biochar and its effects on plant productivity and nutrient cycling: a meta-analysis. GCB Bioenergy 5, 202-214. doi: $10.1111 / \mathrm{gcbb} .12037$

Blackshaw, R. E., and Brandt, R. N. (2008). Nitrogen fertilizer rate effects on weed competitiveness is species dependent. Weed Sci. 56, 743-747. doi: 10.1614/ws-08-065.1

Bonifas, K. D., and Lindquist, J. L. (2006). Predicting biomass partitioning to root versus shoot in corn and velvetleaf (Abutilon theophrasti). Weed Sci. 54, 133-137. doi: 10.1614/WS-05-079R1.1

Bonifas, K. D., and Lindquist, J. L. (2009). Effects of nitrogen supply on the root morphology of corn and velvetleaf. J. Plant Nutr. 32, 1371-1382. doi: $10.1080 / 01904160903007893$

Bonifas, K. D., Walters, D. T., Cassman, K. G., John, L., Walters, D. T., and Cassman, K. G. (2005). Nitrogen supply affects root: shoot ratio in corn and velvetleaf (Abutilon theophrasti). Weed Sci. 53, 670-675. doi: 10.1614/WS-05-002R.1

Brito, I., de Carvalho, M., and Goss, M. J. (2009). "Techniques for arbuscular mycorrhiza inoculum reduction," in Symbiotic Fungi: Principles and Practice, eds A. Varma and A. C. Kharkwal (Berlin: Springer Berlin Heidelberg), 307-318.

Cantrell, K. B., Hunt, P. G., Uchimiya, M., Novak, J. M., and Ro, K. S. (2012). Impact of pyrolysis temperature and manure source on physicochemical characteristics of biochar. Bioresour. Technol. 107, 419-428. doi: $10.1016 /$ j.biortech.2011.11.084

Clark, M., Hastings, M. G., and Ryals, R. (2019). Soil carbon and nitrogen dynamics in two agricultural soils amended with manure-derived biochar. J. Environ. Qual. 48, 727-734. doi: 10.2134/jeq2018.10.0384

Diacono, M., and Montemurro, F. (2010). Long-term effects of organic amendments on soil fertility. A review. Agron. Sustain. Dev. 30, 401-422. doi: 10.1051/agro/2009040

Du, Z. L., Zhao, J. K., Wang, Y. D., and Zhang, Q. Z. (2017). Biochar addition drives soil aggregation and carbon sequestration in aggregate fractions from an intensive agricultural system. J. Soils Sediments 17, 581-589. doi: $10.1007 / \mathrm{s} 11368-015-1349-2$

Feng, G., Song, Y. C., Li, X. L., and Christie, P. (2003). Contribution of arbuscular mycorrhizal fungi to utilization of organic sources of phosphorus by red clover in a calcareous soil. Appl. Soil Ecol. 22, 139-148. doi: 10.1016/S0929-1393(02)00133-6
Dr. Matthew Reid for developing AMF colonization and ERH procedures. We thank Dr. Karen Renner for providing velvetleaf seeds. We also thank Dr. Alexandra Kravchenko and her lab for their help and the use of their total $\mathrm{C} / \mathrm{N}$ processing equipment and MSU's Soil and Plant Nutrient Laboratory for total tissue $\mathrm{P}$ processing.

\section{SUPPLEMENTARY MATERIAL}

The Supplementary Material for this article can be found online at: https://www.frontiersin.org/articles/10.3389/fagro. 2021.731184/full\#supplementary-material

Fidel, R. B., Laird, D. A., and Spokas, K. A. (2018). Sorption of ammonium and nitrate to biochars is electrostatic and pH-dependent. Sci. Rep. 8, 1-10. doi: 10.1038/s41598-018-35534-w

Frey, S. D. (2019). Mycorrhizal fungi as mediators of soil organic matter dynamics. Annu. Rev. Ecol. Evol. Syst. 50, 237-259. doi: 10.1146/annurev-ecolsys-110617-062331

Gale, N., Halim, A., Horsburgh, M., and Thomas, S. C. (2017). Comparative responses of early-successional plants to charcoal soil amendments. Ecosphere 8, 1-18. doi: $10.1002 /$ ecs2.1933

Gao, S., and DeLuca, T. H. (2018). Wood biochar impacts soil phosphorus dynamics and microbial communities in organically-managed croplands. Soil Biol. Biochem. 126, 144-150. doi: 10.1016/j.soilbio.2018. 09.002

Gao, S., DeLuca, T. H., and Cleveland, C. C. (2019). Biochar additions alter phosphorus and nitrogen availability in agricultural ecosystems: a metaanalysis. Sci. Total Environ. 654, 463-472. doi: 10.1016/j.scitotenv.2018. 11.124

Glaser, B., Haumaier, L., Guggenberger, G., and Zech, W. (2001). The "Terra Preta" phenomenon: a model for sustainable agriculture in the humid tropics. Naturwissenschaften 88, 37-41. doi: 10.1007/s001140000193

Gujre, N., Soni, A., Rangan, L., Tsang, D. C. W., and Mitra, S. (2021). Sustainable improvement of soil health utilizing biochar and arbuscular mycorrhizal fungi: a review. Environ. Pollut. 268, 1-17. doi: 10.1016/j.envpol.2020.1 15549

Hammer, E. C., Balogh-Brunstad, Z., Jakobsen, I., Olsson, P. A., Stipp, S. L. S., and Rillig, M. C. (2014). A mycorrhizal fungus grows on biochar and captures phosphorus from its surfaces. Soil Biol. Biochem. 77, 252-260. doi: 10.1016/j.soilbio.2014.06.012

Hoagland, D. R., and Arnon, D. I. (1950). Preparing the Nutrient Solution. WaterCulture Method Grow Plants Without Soil. Berkley, CA: College of Agriculture, University of California.

Hodge, A., Campbell, C. D., and Fitter, A. H. (2001). An arbuscular mycorrhizal fungus accelerates decomposition and acquires nitrogen directly from organic material. Nature 413, 297-299. doi: 10.1038/350 95041

Hodge, A., and Fitter, A. H. (2010). Substantial nitrogen acquisition by arbuscular mycorrhizal fungi from organic material has implications for $\mathrm{N}$ cycling. Proc. Natl. Acad. Sci. U.S.A. 107, 13754-13759. doi: 10.1073/pnas.10058 74107

Hodge, A., and Storer, K. (2014). Arbuscular mycorrhiza and nitrogen: Implications for individual plants through to ecosystems. Plant Soil 386, 1-19. doi: 10.1007/s11104-014-2162-1

Holford, I. C. R. (1997). Soil phosphorus: its measurement, and its uptake by plants. Aust. J. Soil Res. 35, 227-239. doi: 10.1071/S96047

Jakobsen, I., Abbott, L. K., and Robson, A. D. (1992). External hyphae of vesiculararbuscular mycorrhizal fungi associated with Trifolium subterraneum L. 1. Spread of hyphae and phosphorus inflow into roots. New Phytol. 120, 371-380. doi: 10.1111/j.1469-8137.1992.tb01077.x

Jayachandran, K., Schwab, A. P., and Hetrick, B. A. D. (1992). Mineralization of organic phosphorus by vesicular-arbuscular mycorrhizal 
fungi. Soil Biol. Biochem. 24, 897-903. doi: 10.1016/0038-0717(92)9 0012-M

Jeffery, S., Verheijen, F. G. A., van der Velde, M., and Bastos, A. C. (2011). A quantitative review of the effects of biochar application to soils on crop productivity using meta-analysis. Agric. Ecosyst. Environ. 144, 175-187. doi: 10.1016/j.agee.2011.08.015

John, M. K. (1970). Colorimetric determination of phosphorus in soil and plant materials with ascorbic acid. Soil Sci. 109, 214-220. doi: 10.1097/00010694-197004000-00002

Keiluweit, M., Nico, P. S., Johnson, M., and Kleber, M. (2010). Dynamic molecular structure of plant biomass-derived black carbon (biochar). Environ. Sci. Technol. 44, 1247-1253. doi: 10.1021/es9031419

Lehmann, J., and Joseph, S. (2009). Biochar for Environmental Management. London: Earthscan Dunstan House.

Lehmann, J., Rillig, M. C., Thies, J., Masiello, C. A., Hockaday, W. C., and Crowley, D. (2011). Biochar effects on soil biota - a review. Soil Biol. Biochem. 43, 1812-1836. doi: 10.1016/j.soilbio.2011.04.022

Leigh, J., Hodge, A., and Fitter, A. H. (2009). Arbuscular mycorrhizal fungi can transfer substantial amounts of nitrogen to their host plant from organic material. New Phytol. 181, 199-207. doi: 10.1111/j.1469-8137.2008. 02630.x

Li, M., Jordan, N. R., Koide, R. T., Yannarell, A. C., and Davis, A. S. (2016). Meta-analysis of crop and weed growth responses to arbuscular mycorrhizal fungi: implications for integrated weed management. Weed Sci. 64, 642-652. doi: $10.1614 /$ ws-d-16-00050.1

Liao, W., and Thomas, S. (2019). Biochar particle size and post-pyrolysis mechanical processing affect soil $\mathrm{pH}$, water retention capacity, and plant performance. Soil Syst. 3, 1-16. doi: 10.3390/soilsystems30 10014

Lindquist, J. L., Barker, D. C., Knezevic, S. Z., Martin, A. R., and Walters, D. T. (2007). Comparative nitrogen uptake and distribution in corn and velvetleaf (Abutilon theophrasti). Weed Sci. 55, 102-110. doi: 10.1614/ws-0 6-141.1

Lindquist, J. L., and Mortensen, D. A. (1999). Ecophysiological characteristics of four maize hybrids and Abutilon theophrasti. Weed Res. 39, 271-285. doi: 10.1046/j.1365-3180.1999.00143.x

Liu, X., Zhang, A., Ji, C., Joseph, S., Bian, R., Li, L., et al. (2013). Biochar's effect on crop productivity and the dependence on experimental conditions-a meta-analysis of literature data. Plant Soil 373, 583-594. doi: 10.1007/s11104-013-1806-x

Lone, A. H., Najar, G. R., Ganie, M. A., Sofi, J. A., and Ali, T. (2015). Biochar for sustainable soil health: a review of prospects and concerns. Pedosphere 25, 639-653. doi: 10.1016/S1002-0160(15)30045-X

Nash, J., Miesel, J., Bonito, G., Sakalidis, M., Ren, H., Warnock, D., et al. (2021). Biochar alters soil properties, microbial community diversity, and enzyme activities, while decreasing conifer performance. bioRxiv [Preprint]. doi: $10.1101 / 2021.05 .17 .444392$

Major, J., DiTommaso, A., Lehmann, J., and Falcão, N. P. S. (2005). Weed dynamics on Amazonian Dark Earth and adjacent soils of Brazil. Agric. Ecosyst. Environ. 111, 1-12. doi: 10.1016/j.agee.2005.04.019

McGonigle, T. P., Miller, M. H., Evans, D. G., Fairchild, G. L., and Swan, J. A. (1990). A new method which gives an objective measure of colonization of roots by vesicular-arbuscular mycorrhizal fungi. New Phytol. 115, 495-501. doi: 10.1111/j.1469-8137.1990.tb00476.x

Mosse, B. (1973). Advances in the study of vesicular-arbuscular mycorrhiza. Annu. Rev. Phytopathol. 11, 171-196. doi: 10.1146/annurev.py.11.090173.001131

Ocampo, J. A., Martin, J., and Hayman, D. S. (1980). Influence of plant interactions on vesicular-arbuscular mycorrhizal infections. I. Host and non-host plants grown together. New Phytol. 84, 27-35. doi: 10.1111/j.1469-8137.1980.tb00746.x

Patton, C. J., and Kryskalla, J. R. (2011). Colorimetric determination of nitrate plus nitrite in water by enzymatic reduction, automated discrete analyzer methods. U.S. Geol. Surv. Tech. Methods B. 5, 1-34. doi: 10.3133/tm5B8

Phillips, J. M., and Hayman, D. S. (1970). Improved procedures for clearing roots and staining parasitic and vesicular-arbuscular mycorrhizal fungi for rapid assessment of infection. Trans. Br. Mycol. Soc. 55, 158-161. doi: 10.1016/s0007-1536(70)80110-3
Piash, M. I., Iwabuchi, K., Itoh, T., and Uemura, K. (2021). Release of essential plant nutrients from manure- and wood-based biochars. Geoderma 397, 1-12. doi: 10.1016/j.geoderma.2021.115100

Sanders, F. E., and Tinker, P. B. (1971). Mechanism of absorption of phosphate from soil by endogone mycorrhizas. Nature 233, 278-279. doi: $10.1038 / 233278 \mathrm{c} 0$

Schofield, H. K., Pettitt, T. R., Tappin, A. D., Rollinson, G. K., and Fitzsimons, M. F. (2019). Biochar incorporation increased nitrogen and carbon retention in a waste-derived soil. Sci. Total Environ. 690, 1228-1236. doi: 10.1016/j.scitotenv.2019.07.116

Sexton, B. T., Moncrief, J. F., Rosen, C. J., Gupta, S. C., and Cheng, H. H. (1998). Optimizing nitrogen and irrigation inputs for corn based on nitrate leaching and yield on a coarse-textured soil. J. Environ. Qual. 27, 247-247. doi: 10.2134/jeq1998.00472425002700010040x

Sinsabaugh, R. L., Reynolds, H., and Long, T. M. (2000). Rapid assay for amidohydrolase (urease) activity in environmental samples. Soil Biol. Biochem. 32, 2095-2097. doi: 10.1016/S0038-0717(00)0 0102-4

Smith, P. (2016). Soil carbon sequestration and biochar as negative emission technologies. Glob. Chang. Biol. 22, 1315-1324. doi: 10.1111/gcb. 13178

Smith, S. E., and Read, D. (2008). Mycorrhizal Symbiosis. Amsterdam, NL: Elsevier Ltd.

Smith, S. E., and Smith, F. A. (2011). Roles of arbuscular mycorrhizas in plant nutrition and growth: new paradigms from cellular to ecosystem scales. Annu. Rev. Plant Biol. 62, 227-250. doi: 10.1146/annurev-arplant-042110-1 03846

Song, S., Wen, Y., Zhang, J., and Wang, H. (2019). Rapid spectrophotometric measurement with a microplate reader for determining phosphorus in $\mathrm{NaHCO}_{3}$ soil extracts. Microchem. J. 146, 210-213. doi: 10.1016/j.microc.2019.01.002

Spencer, N. R. (1984). Velvetleaf, Abutilon theophrasti (malvaceae), history and economic impact in the United States. Econ. Bot. 38, 407-416. doi: $10.1007 / \mathrm{BF} 02859079$

Staddon, P. L., Fitter, A. H., and Graves, J. D. (1999). Effect of elevated atmospheric $\mathrm{CO}_{2}$ on mycorrhizal colonization, external mycorrhizal hyphal production and phosphorus inflow in Plantago lanceolata and Trifolium repens in association with the arbuscular mycorrhizal fungus Glomus mosseae. Glob. Chang. Biol. 5, 347-358. doi: 10.1046/j.1365-2486.1999.0 0230.x

Stanley, M. R., Koide, R. T., and Shumway, D. L. (1993). Mycorrhizal symbiosis increases growth, reproduction and recruitment of Abutilon theophrasti Medic. in the field. Oecologia 94, 30-35. doi: 10.1007/BF003 17297

Tarafdar, J. C., and Marschner, H. (1994). Phosphatase activity in the rhizosphere and hyphosphere of VA mycorrhizal wheat supplied with inorganic and organic phosphorus. Soil Biol. Biochem. 26, 387-395. doi: 10.1016/0038-0717(94)90288-7

Treseder, K. K. (2013). The extent of mycorrhizal colonization of roots and its influence on plant growth and phosphorus content. Plant Soil 371, 1-13. doi: 10.1007/s11104-013-1681-5

Vatovec, C., Jordan, N., and Huerd, S. (2005). Responsiveness of certain agronomic weed species to arbuscular mycorrhizal fungi. Renew. Agric. Food Syst. 20, 181-189. doi: 10.1079/raf2005115

Vitousek, P. M., Porder, S., Houlton, B. Z., and Chadwick, O. A. (2010). Terrestrial phosphorus limitation: Mechanisms, implications, and nitrogen-phosphorus interactions. Ecol. Appl. 20, 5-15. doi: 10.1890/080127.1

Wang, W., Shi, J., Xie, Q., Jiang, Y., Yu, N., and Wang, E. (2017). Nutrient exchange and regulation in arbuscular mycorrhizal symbiosis. Mol. Plant 10, 1147-1158. doi: 10.1016/j.molp.2017.07.012

Warnock, D. D., Lehmann, J., Kuyper, T. W., and Rillig, M. C. (2007). Mycorrhizal responses to biochar in soil - concepts and mechanisms. Plant Soil 300, 9-20. doi: 10.1007/s11104-007-9391-5

Whiteside, M. D., Garcia, M. O., and Treseder, K. K. (2012). Amino acid uptake in arbuscular mycorrhizal plants. PLOS ONE 7:e0047643. doi: 10.1371/journal.pone.0047643 
Yamato, M., Okimori, Y., Wibowo, I. F., Anshori, S., and Ogawa, M. (2006). Effects of the application of charred bark of Acacia mangium on the yield of maize, cowpea and peanut, and soil chemical properties in South Sumatra, Indonesia. Soil Sci. Plant Nutr. 52, 489-495. doi: 10.1111/j.1747-0765.2006.0 0065.x

Zhang, H., Chen, C., Gray, E. M., Boyd, S. E., Yang, H., and Zhang, D. (2016). Roles of biochar in improving phosphorus availability in soils: A phosphate adsorbent and a source of available phosphorus. Geoderma 276, 1-6. doi: 10.1016/j.geoderma.2016.04.020

Conflict of Interest: The authors declare that the research was conducted in the absence of any commercial or financial relationships that could be construed as a potential conflict of interest.
Publisher's Note: All claims expressed in this article are solely those of the authors and do not necessarily represent those of their affiliated organizations, or those of the publisher, the editors and the reviewers. Any product that may be evaluated in this article, or claim that may be made by its manufacturer, is not guaranteed or endorsed by the publisher.

Copyright (C) 2021 O'Neil, Nash, Tiemann and Miesel. This is an open-access article distributed under the terms of the Creative Commons Attribution License (CC BY).

The use, distribution or reproduction in other forums is permitted, provided the original author(s) and the copyright owner(s) are credited and that the original publication in this journal is cited, in accordance with accepted academic practice. No use, distribution or reproduction is permitted which does not comply with these terms. 